\title{
DRIVERS OF SHORT-TERM OVERPRODUCTION: EXCESS CAPITAL INVESTMENT AND PRODUCTION DECISIONS BASED ON PAST INFORMATION
}

\author{
Haihong $\mathrm{He}$
}

The BRC Academy Journal of Business 9, no. 1 (2019): 45-60.

http://dx.doi.org/10.15239/j.brcacadjb.2019.09.01.ja03

\section{Web APPENDIX}

http://dx.doi.org/10.15239/j.brcacadjb.2019.09.01.wa03

Table 1 Descriptive Statistics

Panel A Variables Used in Testing H1

\begin{tabular}{lllllll}
\hline & Mean & Std & Q1 & Median & Q3 & N \\
\hline CPAI & -0.00715 & 0.2146 & -0.0434 & 0 & 0.0389 & 9,480 \\
$\Delta \mathrm{FA}_{\mathrm{t}}$ & 0.000246 & 0.0680 & -0.0201 & -0.00407 & 0.0169 & 9,480 \\
$\Delta \mathrm{FA}_{\mathrm{t}-1}$ & 0.000483 & 0.7866 & -0.0243 & -0.00712 & 0.0158 & 9,480 \\
$\Delta \Delta \mathrm{FA}_{\mathrm{t}-1}$ & 0.000562 & 0.7876 & -0.0271 & -0.00944 & 0.0154 & 9,480 \\
Log(AT) & 5.5715 & 2.5107 & 3.9180 & 5.6370 & 7.3277 & 9,480 \\
Tobin's Q & 3.2245 & 37.2464 & 0.8894 & 1.3613 & 2.3288 & 9,480 \\
Industry & 0.0404 & 0.1127 & 0.0121 & 0.0440 & 0.0879 & 9,480 \\
Growth & & & & & &
\end{tabular}




\section{Panel B Variables Used in Testing Research Question 2}

\begin{tabular}{lllllll}
\hline & Mean & Std & Q1 & Median & Q3 & $\mathrm{N}$ \\
\hline CPAI & -0.0051 & 0.1891 & -0.0410 & 0.0000 & 0.0372 & 10,266 \\
Prod $_{t} / \mathrm{TA}_{\mathrm{t}-1}$ & 0.7484 & 1.7768 & 0.3432 & 0.5911 & 0.9222 & 10,266 \\
Sales $_{\mathrm{t}-1} / \mathrm{TA}_{\mathrm{t}-1}$ & 0.9590 & 0.5840 & 0.5801 & 0.8818 & 1.2610 & 10,266 \\
Sales $_{\mathrm{t}} / \mathrm{TA}_{\mathrm{t}-1}$ & 1.0068 & 0.6136 & 0.6077 & 0.9323 & 1.3143 & 10,266 \\
Sales $_{\mathrm{t}+1} / \mathrm{TA}_{\mathrm{t}-1}$ & 1.0589 & 0.6911 & 0.6156 & 0.9542 & 1.3771 & 10,266 \\
\hline
\end{tabular}

CPAI is calculated as $\Delta \mathrm{INV}_{\mathrm{t}} /\left(\mathrm{COGS}_{\mathrm{t}}+\Delta \mathrm{INV}_{\mathrm{t}}\right)-\Delta \mathrm{INV}_{\mathrm{t}-1} /\left(\mathrm{COGS}_{\mathrm{t}-1}+\Delta \mathrm{INV}_{\mathrm{t}-1}\right)$. In the expression, $\Delta \mathrm{INV}_{\mathrm{t}}$ and $\Delta \mathrm{INV} \mathrm{t}_{\mathrm{t}-1}$ represent a firm's annual inventory change in years $\mathrm{t}$ and $\mathrm{t}-1$, respectively, calculated based on total (absorption-costing based) inventory value (COMPUSTAT DATA\#3). COGS represents a firm's cost of goods sold (COMPUSTAT DATA\#41), adjusted upward for depreciation expense (DATA\#14).

$\Delta \mathrm{FA}_{\mathrm{t}}$ is excess production capacity in year $\mathrm{t}$, which is computed as change in gross fixed assets scaled by total assets minus corresponding industry mean based on two digit SIC code.

Similarly, we calculated $\Delta \mathrm{FA}_{\mathrm{t}-1}$ and $\Delta \mathrm{FA}_{\mathrm{t}-2}$ in years $\mathrm{t}-1$ and $\mathrm{t}-2$, respectively.

$\log (\mathrm{AT})$ is natural logarithm of total assets to proxy for business size ( $\log (\mathrm{AT}))$.

Tobin's Q is calculated as (market value of equity + total liability)/total assets.

Industry Growth is the mean of industry sales changes to proxy for the industry business growth.

Prod $\mathrm{TA}_{\mathrm{t}-1}$ is the sum of the cost of goods sold and the change in inventory during the year

scaled by total assets at the beginning of the year.

Sales $\mathrm{t}_{-1} / \mathrm{TA}_{\mathrm{t}-1}$ is prior year sales scaled by total assets at the beginning of the year.

Sales $_{t} / \mathrm{TA}_{\mathrm{t}-1}$ is current year sales scaled by total assets at the beginning of the year.

Sales $_{t+1} / \mathrm{TA}_{\mathrm{t}-1}$ is future year sales scaled by total assets at the beginning of the year. 


\section{Table 2 Regression Results of Equation (1) to Test H1}

$$
\mathrm{CPAI}_{\mathrm{t}}=\alpha 0+\alpha 1 \Delta \mathrm{FA}_{\mathrm{t}}+\alpha 2 \Delta \mathrm{FA}_{\mathrm{t}-1}+\alpha 3 \Delta \mathrm{FA}_{\mathrm{t}-2}+\text { ControlVariables }+\varepsilon_{\mathrm{t}}
$$

\begin{tabular}{|c|c|}
\hline & Estimated Coefficient \\
\hline Intercept & $\begin{array}{l}-0.0074 * * * \\
(14.30)\end{array}$ \\
\hline$\Delta \mathrm{FA}_{\mathrm{t}}$ & $\begin{array}{l}0.1007^{* * * *} \\
(76.53)\end{array}$ \\
\hline$\Delta \mathrm{FA}_{\mathrm{t}-1}$ & $\begin{array}{l}-0.0009 \\
(0.89)\end{array}$ \\
\hline$\Delta \mathrm{FA}_{\mathrm{t}-2}$ & $\begin{array}{l}0.0006 \\
(0.36)\end{array}$ \\
\hline $\log (\mathrm{AT})$ & $\begin{array}{l}-0.0000 \\
(0.01)\end{array}$ \\
\hline Tobin's Q & $\begin{array}{l}-0.0000 \\
(0.06)\end{array}$ \\
\hline Industry Growth & $\begin{array}{l}0.1432 * * * \\
(425.89)\end{array}$ \\
\hline Adj. $R^{2}$ & 0.0184 \\
\hline $\mathrm{N}$ & 9,480 \\
\hline
\end{tabular}

***,**,* statistically significant at the 1 percent, 5 percent, 10 percent levels for a two-tailed test.

CPAI is calculated as $\Delta \mathrm{INV}_{\mathrm{t}} /\left(\mathrm{COGS}_{\mathrm{t}}+\Delta \mathrm{INV}_{\mathrm{t}}\right)-\Delta \mathrm{INV}_{\mathrm{t}-1} /\left(\mathrm{COGS}_{\mathrm{t}-1}+\Delta \mathrm{INV}_{\mathrm{t}-1}\right)$. In the expression, $\Delta \mathrm{INV}_{\mathrm{t}}$ and $\Delta \mathrm{INV}_{\mathrm{t}-1}$ represent a firm's annual inventory change in years $\mathrm{t}$ and $\mathrm{t}-1$, respectively, 
calculated based on total (absorption-costing based) inventory value (COMPUSTAT DATA\#3). COGS represents a firm's cost of goods sold (COMPUSTAT DATA\#41), adjusted upward for depreciation expense (DATA\#14).

$\Delta F A_{t}$ is excess production capacity in year $t$, which is computed as change in gross fixed assets scaled by total assets minus corresponding industry mean based on two digit SIC code.

Similarly, we calculated $\Delta \mathrm{FA}_{\mathrm{t}-1}$ and $\Delta \mathrm{FA} \mathrm{t}_{\mathrm{t}-2}$ in years $\mathrm{t}-1$ and $\mathrm{t}-2$, respectively.

$\log (\mathrm{AT})$ is natural logarithm of total assets to proxy for business size $(\log (\mathrm{AT}))$.

Tobin's Q is calculated as (market value of equity + total liability)/total assets.

Industry Growth is the mean of industry sales changes to proxy for the industry business growth. 
Table 3 Regression Results of Equation (2) to Test Research Question 2

$\operatorname{Prod}_{t} / \mathrm{TA}_{\mathrm{t}-1}=\alpha 0+\alpha 1\left(1 / \mathrm{TA}_{\mathrm{t}}\right)+\alpha 2\left(\operatorname{Sales}_{\mathrm{t}-1} / \mathrm{TA}_{\mathrm{t}-1}\right)+\alpha 3\left(\mathrm{Sales}_{\mathrm{t}} / \mathrm{TA}_{\mathrm{t}-1}\right)+\alpha 4\left(\operatorname{Sales}_{\mathrm{t}+1} / \mathrm{TA}_{\mathrm{t}-1}\right)+\varepsilon$

Panel A Sample Partitioned by CPAI Quartile

\begin{tabular}{|c|c|c|c|c|}
\hline & Q1 & Q2 & Q3 & $\mathrm{Q} 4$ \\
\hline Intercept & $-0.0478 * * *$ & $0.0186^{* *}$ & $0.0293 * * *$ & $-0.1064 * * *$ \\
\hline $1 / \mathrm{TA}_{\mathrm{t}-1}$ & $0.1761^{* * *}$ & $0.0258 * * *$ & $0.9124 * * *$ & $0.0991 * * *$ \\
\hline Sales $_{t-1} / \mathrm{TA}_{\mathrm{t}-1}$ & -0.0216 & 0.0047 & 0.0036 & $0.0602^{* * *}$ \\
\hline Sales $_{t} / \mathrm{TA}_{\mathrm{t}-1}$ & $0.7660 * * *$ & $0.6777 * * *$ & $0.6193 * * *$ & $0.5865 * * *$ \\
\hline Sales $_{\mathrm{t}+1} / \mathrm{TA}_{\mathrm{t}-1}$ & $-0.1122 * * *$ & $-0.0388^{*}$ & $0.0588 * * *$ & $0.0862 * * *$ \\
\hline Adj. $R^{2}$ & 0.4605 & 0.3784 & 0.4507 & 0.5898 \\
\hline $\mathrm{N}$ & 2,650 & 2,578 & 2,475 & 2,563 \\
\hline
\end{tabular}




\section{Panel B Sample Partitioned by CPAI Signs}

\begin{tabular}{|c|c|c|}
\hline & CPAI $<=0$ & CPAI $>0$ \\
\hline Intercept & 0.0096 & $-0.1188^{* * *}$ \\
\hline $1 / \mathrm{TA}_{\mathrm{t}-1}$ & $0.7142 * * *$ & $0.1121 * * *$ \\
\hline Sales $_{t-1} / \mathrm{TA}_{\mathrm{t}-1}$ & 0.0215 & $0.0427 * * *$ \\
\hline Sales $_{t} / \mathrm{TA}_{\mathrm{t}-1}$ & $0.6875^{* * *}$ & $0.6760 * * *$ \\
\hline Sales $_{t+1} / \mathrm{TA}_{\mathrm{t}-1}$ & $-0.0743 * * *$ & $0.0575 * * *$ \\
\hline Adj. $\mathrm{R}^{2}$ & 0.3464 & 0.5976 \\
\hline $\mathrm{N}$ & 5,588 & 4,678 \\
\hline
\end{tabular}

$* * *, * *, *$ statistically significant at the 1 percent, 5 percent, 10 percent levels for a two-tailed test.

CPAI is calculated as $\Delta \mathrm{INV}_{\mathrm{t}} /\left(\mathrm{COGS}_{\mathrm{t}}+\Delta \mathrm{INV}_{\mathrm{t}}\right)-\Delta \mathrm{INV}_{\mathrm{t}-1} /\left(\mathrm{COGS}_{\mathrm{t}-1}+\Delta \mathrm{INV}_{\mathrm{t}-1}\right)$. In the expression, $\Delta \mathrm{INV}_{\mathrm{t}}$ and $\Delta \mathrm{INV}_{\mathrm{t}-1}$ represent a firm's annual inventory change in years $\mathrm{t}$ and $\mathrm{t}-1$, respectively, calculated based on total (absorption-costing based) inventory value (COMPUSTAT DATA\#3). COGS represents a firm's cost of goods sold (COMPUSTAT DATA\#41), adjusted upward for depreciation expense (DATA\#14).

$\operatorname{Prod}_{t} / \mathrm{TA}_{\mathrm{t}-1}$ is the sum of the cost of goods sold and the change in inventory during the year

scaled by total assets at the beginning of the year.

Sales $_{\mathrm{t}-1} / \mathrm{TA}_{\mathrm{t}-1}$ is prior year sales scaled by total assets at the beginning of the year. 
Sales $t / \mathrm{TA}_{\mathrm{t}-1}$ is current year sales scaled by total assets at the beginning of the year.

Sales $_{t+1} / \mathrm{TA}_{\mathrm{t}-1}$ is future year sales scaled by total assets at the beginning of the year. 